\title{
You Can't Teach Speed: Sprinters Falsify the Deliberate Practice Model of Expertise
}

Many scientists agree that expertise requires both innate talent and proper training.

Nevertheless, the highly influential deliberate practice model (DPM) of expertise holds that talent does not exist or makes a negligible contribution to performance. It predicts that initial performance will be unrelated to achieving expertise and that 10 years of deliberate practice is necessary. We tested these predictions in the domain of sprinting. In Studies 1 and 2 we reviewed biographies of 15 Olympic champions and the 20 fastest American men in U.S. history. In all documented cases, sprinters were exceptional prior to initiating training, and most reached world class status rapidly (Study 1 median $=3$ years; Study $2=7.5$ ). In Study 3 we surveyed U.S. national collegiate championships qualifiers in sprints and throws. Sprinters recalled being faster as youths than did throwers, whereas throwers recalled greater strength and throwing ability. Sprinters' best performances in their first season of high school, generally the onset of formal training, were consistently faster than $95-99 \%$ of their peers. Collectively, these results falsify the DPM for sprinting. Because speed is foundational for many sports, they challenge the DPM generally. 
1 You Can't Teach Speed: Sprinters Falsify the Deliberate Practice Model of Expertise

\section{Authors and Affiliations}

3 Michael P. Lombardo ${ }^{1}$

4 Robert O. Deaner ${ }^{2}$

$5{ }^{1}$ Department of Biology, Grand Valley State University, Allendale, Michigan, United States of

6 America

$7 \quad{ }^{2}$ Department of Psychology, Grand Valley State University, Allendale, Michigan, United States

8 of America 


\section{Abstract}

10 Many scientists agree that expertise requires both innate talent and proper training. Nevertheless,

11 the highly influential deliberate practice model (DPM) of expertise holds that talent does not exist

12 or makes a negligible contribution to performance. It predicts that initial performance will be

13 unrelated to achieving expertise and that 10 years of deliberate practice is necessary. We tested

14 these predictions in the domain of sprinting. In Studies 1 and 2 we reviewed biographies of 15

15 Olympic champions and the 20 fastest American men in U.S. history. In all documented cases,

16 sprinters were exceptional prior to initiating training, and most reached world class status rapidly

17 (Study 1 median $=3$ years; Study $2=7.5$ ). In Study 3 we surveyed U.S. national collegiate

18 championships qualifiers in sprints $(n=20)$ and throws $(n=44)$. Sprinters recalled being faster as

19 youths than did throwers, whereas throwers recalled greater strength and throwing ability.

20 Sprinters' best performances in their first season of high school, generally the onset of formal

21 training, were consistently faster than $95-99 \%$ of their peers. Collectively, these results falsify the

22 DPM for sprinting. Because speed is foundational for many sports, they challenge the DPM

23 generally. 


\section{Introduction}

27 A major scientific goal is identifying the factors that contribute to expertise or superior

28 performance in domains such as dancing, decision-based games (e.g., chess), music, professional

29 decision-making (e.g., medical diagnosis), and sports.

Many contemporary scientists hold that the phenotypic expression of traits, including

those associated with expertise, reflect an interaction between genes (i.e., nature) and experience

32 (i.e., nurture)[1,2]. However, some hold that experience might, by itself, be sufficient to account

33 for expertise [3-6]. These scholars have developed and endorsed a deliberate practice model

34 (DPM) of expertise which emphasizes the crucial role of deliberate practice, defined as training

35 that is structured, attentive, maximally effortful, and subject to immediate feedback from a coach

36 [3-6]. The DPM, at least the strong version addressed here, holds that consistent long period of

37 deliberate practice (about 10 years or 10,000 hours) is necessary and sufficient for any healthy

38 individual to achieve expert performance in any domain [3-5]. The only acknowledged

39 exceptions are for domains where success is dependent on body size and/or height, such as

40 basketball [7,8]. Representative claims by DPM advocates are provided in Table S1.

41 The DPM has been enormously successful in stimulating research on the mechanisms

42 (e.g., physiological, motor, perceptual, cognitive) and the kinds of training (e.g., social or solitary,

43 leisurely or concentrated) that underlie expert performance [9-12]. This impact is revealed by the

44 fact that as of 10 April 2014, the foundational DPM paper by Ericsson, Krampe, and Tesch-

45 Römer [3] has been cited over 4200 times on Google Scholar. The DPM's influence extends

46 beyond academia, as it has served as the basis for several popular trade books [13-15].

47 Despite the DPM's popularity, there are strong theoretical and empirical reasons to doubt 
48 its fundamental claim that deliberate practice is necessary and sufficient for achieving expertise.

49 First, from a theoretical perspective, the assumptions of the DPM are inconsistent with mounting

50 literature documenting the influence of an individual's genotype on its behavior [16,17] and

51 physiological performance [18-20]. In addition, the DPM may not adequately explain or predict

52 the development of expert performance in motor dominated domains because of its emphasis on

53 cognitive mechanisms [21]. Moreover, evolutionary hypotheses for the existence of display or

54 "show-off" expertise domains hold that, in large part, expert performances are impressive

55 precisely because they function to signal heritable genetic variation [22-26].

Second, empirical work indicates that foundational abilities for some expertise domains

have a heritable genetic basis [27,28]. For instance, working memory capacity is highly heritable

[29], and, even when the amount of deliberate practice is controlled, it predicts performance in

poker [30] and piano playing [31]. Similarly, maximal oxygen consumption $\left(\mathrm{VO}_{2} \max \right)$ is crucial

for elite performance in endurance sports, and both untrained $\mathrm{VO}_{2}$ max and $\mathrm{VO}_{2} \max$ responsiveness are highly heritable [32,33].

Third, scientists have noted weaknesses in the behavioral evidence that directly addresses

63 the DPM's claims The DPM is based on correlational studies showing that achievement is

64 strongly correlated with accumulated deliberate practice. One problem with the DPM is that it assumes that deliberate practice drives the correlation, yet it is possible that innate ability, or talent, is causal [34]. In other words, individuals that experience early success as a result of superior innate ability typically become more motivated to train [6]. For example, in the domain of music expertise, Ruthsatz et al. [35] reanalyzed the data in Ericsson et al. [3] and showed that, even as young children, the violinists who would eventually accumulate a large amount of deliberate practice (about 10,000 hours on average) and become elite were already more likely than others to win competitions despite training for similar durations as those who would not

72 become not become as accomplished. 
A fourth problem with the DPM is its claim that deliberate practice explains a very high

74 proportion of the variance in the attainment of expertise; the empirical data contradict this [36].

75 For example, deliberate practice explained only $28 \%$ of performance variation among dart

76 players [37]. Among chess players, deliberate practice explained only $34 \%$ of performance

77 variation. And in fact, some chess players did not reach the master level despite 25,000 hr of

78 practice, whereas others reached this level with only 3,000 hr of practice [38]. Similarly, a study

79 of 459 elite Australian athletes from 34 different sports demonstrated that the mean period of

80 development from novice to elite athlete was $7.5 \pm 4.1$ (SD) years, and $69 \%$ of athletes in

81 individual sports achieved elite status in less than five years [39].

82 Although these appear to be intractable empirical problems for the DPM's strong claims,

83 DPM proponents have presented counter-arguments [3,5,6,40]. For example, Ericsson et al. [5]

84 and Ericsson [40] disputed the heritability of $\mathrm{VO}_{2} \max$ and other physiological factors relevant to

85 sports performance [18,19,28,32,33]. In addition, Howe et al. [6] noted that modest correlations

86 between deliberate practice and achievement might reflect unequal quality of instruction or

87 effectiveness of practice strategy. In sum, then, there remains uncertainty regarding the validity of

88 the DPM.

89 Here we provide strong tests of two critical DPM predictions in the domain of sprinting

90 (e.g., footraces over short distances such as $100 \mathrm{~m}$ ). First, we tested the DPM's prediction that

91 initial performance in a domain (i.e., prior to deliberate practice) and final performance in the

92 domain will be unrelated. Although there has been much discussion about prodigies, since their

93 occurrence would falsify the DPM, it is impossible to assess whether an individual is exceptional

94 prior to training in most domains [3,6]. For example, it makes little sense to ask, much less

95 measure, how gifted a child is at playing chess before they have become knowledgeable about the

96 rules of the game. In the domain of sprinting, however, it is possible to assess performance prior

97 to training. This is because nearly all children run in the course of normal play. Thus, a child who 
98 is an exceptionally fast runner can readily assess their ability relative to their peers, as can adult

99 observers. The DPM implies that initial performance in a domain represents random error and

100 that only formal training determines an individual's ultimate level of performance. In contrast, an

101 interactive "talent matters" framework predicts that, as children, most elite sprinters will have

102 been fast relative to their peers and that these individuals will have performed exceptionally well

103 as soon as they began formal competition and training.

104 Second, we tested the DPM's prediction that roughly 10 years of deliberate practice are

105 required to reach expert status. Although some studies indicate that some athletes reach expert

106 status with substantially less than 10 years of training [39], several others are consistent with the

107 "10 year rule" [11,41-46]. In addition, a limitation of most studies is that there is some degree of

108 subjectivity in the rating of expertise. For example, factors related to team selection (e.g., a coach

109 preferring older players [47]) may mean that a soccer or field hockey player may not play for his

110 or her national team (and thus be classified as an expert) until his or her mid-20s despite having

111 the ability to do so several years earlier. Because sprinting expertise is based on objective

112 performances, it provides an unusually strong test of the DPM's main prediction that 10 years or

$11310,000 \mathrm{hr}$ of deliberate practice are required to achieve expert performance.

114 We tested the two key predictions of the DPM with three complementary studies. In Study

1151 we reviewed the biographies of male and female Olympic sprint champions. In Study 2 we

116 reviewed the biographies of the 20 fastest male $100 \mathrm{~m}$ runners in U.S. history. In Study 3 we

117 surveyed male and female sprinters who qualified for the 2012 U.S. collegiate national

118 championships. To our knowledge, these are the first studies to address the DPM in sprinting.

\section{Study 1: Biographies of Olympic champions}

120 We examined the biographies of Olympic champions because becoming an Olympic champion

121 shows unambiguous evidence of expertise. Moreover, because there is often great interest in

122 sprint champions, biographies have been written about many of them. These generally include 
123 detailed information on the sprinter's athletic development, making them ideal for addressing the

124 predictions of interest.

125 Although our main focus was testing the two predictions discussed above, we also

126 explored whether champion sprinters had participated in organized sports prior to beginning their

127 sprinting career. This was important because it could be argued that exceptional sprinting

128 performance prior to formal sprint training reflects skill transfer from other sports $[48,49]$.

129 Methods

130 We sought English-language biographies, including autobiographies, published in print of male

131 and female gold medalists in the $100 \mathrm{~m}$ or $200 \mathrm{~m}$ sprints from the 1896 to 2012 Olympic Games.

132 We were able to obtain at least one biography for 15 sprinters (8 women) and obtained two or

133 more biographies for six sprinters. Two of the champion sprinters, Ben Johnson in 1988 and

134 Marion Jones in 2000, were later stripped of their gold medals due to their use of performance

135 enhancing drugs (PEDs). We retained these sprinters in the sample because the available

136 information indicated that they reached world class status before they began using PEDs.

137 Furthermore, the use of PEDs may be common among world class sprinters, even those who are

138 never sanctioned $[50,51]$.

139 From the biographies, we recorded any evaluation of the sprinter being exceptional or

140 unexceptional relative to their peers. We recorded who made the evaluation, the sprinter, a

141 teacher, or a coach, or another individual. We recorded the sprinter's age when the evaluation

142 occurred and the age when they began formal training with a coach. We assumed that formal

143 training with a coach would indicate the onset of training activities that would best correspond

144 with "deliberate practice." In some cases, the sprinter's age at the time of first evaluation or first

145 formal training was not mentioned, but their grade in school was, and this allowed us to estimate

146 their age. For instance, the first year of high school was assumed to indicate being age 14 years.

147 In cases where there was no explicit mention of the initiation of formal training, we assumed this 
169 schoolboy [55].

170 
174 of any kind prior to the recognition of their superior sprinting ability or their initiation of 175 deliberate sprint practice.

176 The results of this study clearly contradict the DPM: sprinters were consistently fast prior

177 to formal training, achieved world class status in much less than ten years, and, in most cases,

178 their exceptional development cannot be attributed to skill transfer. Nonetheless, this study has

179 two possible limitations. First, the sample size of 15 is modest. Second, many of the individuals

180 became Olympic champions several decades ago. Because world class sprint performances have

181 continued to improve [56], this raises the question of whether our results would differ if we used

182 a more contemporary sample of sprinters. Study 2 was designed to address these limitations.

183 Study 2: Biographies of fastest 20 U. S. males of all time

184 In Study 2, we examined the development of the 20 fastest male U.S. $100 \mathrm{~m}$ sprinters. This is an 185 excellent sample because the U.S. has been one of the strongest sprinting countries since the 186 onset of modern international competition and record keeping [57]. This is revealed by the fact 187 that 14 of 20 of these men won at least one individual World Championship or Olympic sprint 188 medal $(100 \mathrm{~m}, 200 \mathrm{~m}$, or $60 \mathrm{~m}$ indoors); four of the others have won at least one relay medal at 189 the World or Olympic championships. Moreover, all of these men achieved performances that 190 meet contemporary standards of world class performance, including the 2012 Olympic A

191 Qualifying Standard (i.e., 10.18 s automatically qualifying them to participate in the Olympic 192 Games; www.usatf.org).

193 We again examined whether these sprinters were exceptional prior to initiating formal 194 training and how long it took for them to reach world class status. We also searched for evidence 195 indicating that these men were unexceptional relative to their peers prior to their beginning 196 formal sprint training. 
198 percentage of improvement after age 19. The DPM makes no quantitative claim regarding the

199 magnitude of improvement among regularly training adult athletes. However, the "talent matters"

200 framework implies that once athletes have reached physical maturity and done some formal

201 training, subsequent improvements will be relatively modest. 


\section{Methods}

203 We used methods similar to those in Study 1 with the following two caveats. First, with the

204

205

206

207

208

209

210

211

212

213

214

215

216

217

218

219

220

221

222

223

224

225

226

exception of Carl Lewis, book length biographies were not available for these athletes. We thus obtained information from magazines, newspapers, and internet sources. Second, we classified athletes as first reaching world class status upon first meeting either of the following criteria: (1) representing the U.S. in international competition (e.g., Olympic Games, World Championships, Pan American Games in an individual sprint event or as a member of a relay team) or (2) participating in the U.S. Olympic Trials which requires the athlete to meet Olympic A or B standards to qualify to compete at the Trials. Four of these athletes (Gatlin, Mitchell, Montgomery, Williams) were sanctioned for using PEDs at least once in their careers. Eight of the 20 sprinters (Bailey, Crawford, Dix, Gatlin, Gay, Padgett, Patton, Williams) competed in 2012 when we finished gathering data for this study. One athlete, Carl Lewis, was also included in Study 1 .

We obtained information on athletes' best performance at the age 19 from U. S. A. Track and Field (www.usatf.org), International Association of Athletics Federation (www.iaaf.org), or track and field historian Walter Murphy (pers. comm., 3 April 2011). We choose age 19 as a convenient cut-off age for comparisons between early and life-time fastest sprint performances because IAAF defines a Junior athlete as one who is 19 years of age or younger (www.iaaf.org). We obtained lifetime personal best performances from U. S. A. Track and Field (www.usatf.org). For these best performances, we only counted times that were legal (i.e., not wind-aided, wind less than $2 \mathrm{~m}$ per second).

In order to provide a more comprehensive picture of improvement, we plotted yearly best performances for the fastest 10 sprinters in this sample and plotted them as a function of age. We obtained data (though 31 December 2013) from the International Association of Athletics Federation (www.iaaf.org) and again only included legal times. 


\section{Results and Discussion}

228 We were able to obtain information regarding the development of 12 of 20 sprinters, and these

229 data are summarized in Table 2. All 12 were recognized as exceptionally fast relative to their

230 peers before or coincident with their initiation of formal training. There was no indication that

231 any sprinter was initially unexceptional.

232 In nine cases, adults reportedly first recognized a sprinter's talent. Leroy Burrell [58] and

233 Bernard Williams [59] were discovered while they played baseball and basketball, respectively,

234 whereas track coaches identified the superior abilities of the other seven. In the cases of Carl

235 Lewis and Walter Dix, their parents were the track coaches [60,61].

236 Eight of the 12 sprinters for whom relevant data were available required less than 10 years

237 of deliberate practice to achieve world class status (median $=7.5$ years; mean $=8.7 \pm 3.8$; Table

238 2, Fig. 2).

239

Fastest $100 \mathrm{~m}$ times at age 19 were available for 19 of the sprinters (Table 2). They

240 showed only modest improvement between their fastest time at age 19 and their personal record

241 (mean improvement $=3.3 \pm 1.5 \%$; Table 2 ). They typically achieved their fastest time in their

242 mid-20s $($ median $=24.8$ years, $25.2 \pm 2.6$ years; Table 2$)$.

243 The trajectories of $100 \mathrm{~m}$ performance improvement as a function of age are displayed in

244 Figure S1. These show, both individually and collectively, that sprinters' abilities generally

245 improve from their late teens until their mid-twenties and then gradually decline. Presumably, the

246 improvement generally reflects physical maturation and training and the decline reflects

247 senescence. These trajectories must also be affected by other factors, such as motivation, injuries,

248 racing conditions, and the use of performance enhancing drugs.

249 One concern about Study 1 and Study 2 is that 10 years might not have been necessary to

250 achieve expertise for many sprinters because PEDS accelerated their development. This issue

251 warrants consideration, but, for several reasons, the use of PEDs cannot provide a genuine 
252 defense for the DPM. First, some sprinters in Study 1 performed before the PEDS believed to

253 substantially help sprinters (e.g., anabolic steroids) would have been available to them. It is

254 thought that weightlifters and bodybuilders in East Germany, the USSR, and the USA first used

255 anabolic steroids in the 1950s [62,63]. Anabolic steroids did not become widely used by track and

256 field athletes until after the 1960 Olympics [63]. Thus, PEDs seem unable to explain the rapid

257 development of Jesse Owens, Helen Stephens, Wilma Rudolph, and Bob Hayes. Second, the

258 biographies of Ben Johnson and Marion Jones indicated they began using PEDs after they had

259 achieved world class performances. These athletes and their coaches acknowledged that PEDs

260 allowed them to run faster, but stated that the gains, although certainly meaningful in allowing

261 them to beat their competitors, were proportionally modest. At the 1989 Canada Commission of

262 Inquiry into the Use of Drugs and Banned Practices Intended to Increase Athletic Performance,

263 Ben Johnson's coach, Charlie Francis, testified, “It's pretty clear that steroids are worth

264 approximately a meter [in the 100 meters] at the highest levels. He [Ben Johnson] could decide to

265 set up his starting blocks at the same line as all the other competitors, or set them up a meter

266 behind them all" [64]. A one meter benefit from steroid use is equivalent to $0.1 \mathrm{~s}$ in a $10.0 \mathrm{~s} 100$

267 m sprint. Similarly, recent admissions by Tim Montgomery (see Table 2) indicate that he reached

268 world class status prior to using PEDs and that the performance benefits were proportionally

269 modest, roughly 2-3\% [65]. Thus, PEDs seem unable to provide a plausible explanation for the

270 rapid attainment of world class status by these sprinters.

271

The results of Studies 1 and 2 contradict the DPM's predictions, but they have two

272 plausible limitations with regards to initial performance. First, perhaps the initially exceptional

273 running of elite sprinters does not represent sprinting talent specifically. For example, a child

274 with more overall athletic experience than its peers, or one who physically matures earlier, might

275 be exceptional in almost all areas, and this early success could be a precondition for later 
276 pursuing and excelling in various sports. Second, perhaps sprinters desire to portray themselves

277 as unusually talented and therefore provide false accounts of their abilities. Study 3 was designed

278 to address these limitations.

279 Study 3: Surveys of collegiate sprinters

280 In Study 3, we recruited individual sprint qualifiers for the 2012 National Collegiate Athletics 281 Association (NCAA) national championships to complete an online survey. We asked sprinters

282 about their speed relative to their peers as children and adolescents. To address the specificity of

283 their athletic ability, we also recruited a control group, collegiate throwers (e.g., shot put, discus,

284 javelin) who qualified for these meets. The "talent matters" framework predicts that sprinters

285 generally will recall being faster than their peers as children and adolescents than will the

286 throwers. To further address specificity, we also asked about physical strength and overhand

287 throwing ability. We predicted that throwers would recall being stronger and having better 288 overhand throwing ability as youths than would sprinters.

289 The surveys also allowed us to obtain systematic data on sprinters' performances in their

290 first season of high school competition, which was generally coincident with their onset of formal

291 training. Again, the "talent matters" framework predicts that sprinters will be much faster than

292 most of their peers even at this early stage in their careers, whereas the DPM does not.

\section{Methods}

294 Ethics Statement

295 The Chair of the Human Research Review Committee at Grand Valley State University reviewed 296 the study protocol (Protocol 338194-1) and certified it as approved and exempt from full 297 committee review.

\section{Recruitment of Subjects}

299 We attempted to recruit all male and female individual qualifiers in the $100 \mathrm{~m}, 200 \mathrm{~m}$, and $400 \mathrm{~m}$ 300 sprints and shot put, discus, and javelin throws from the 2012 NCAA Outdoor Track and Field 
301 National Championships; lists were available online (www.ncaa.com). We recruited individuals

302 from Divisions I, II, and III. The Divisions reflect, on average, the financial commitments made

303 by colleges and universities to their athletes. Division I includes the largest athletic programs that

304 provide the most athletically related financial aid for student-athletes, Division II institutions

305 provide athletes limited financial aid, and Division III institutions do not provide athletically

306 related financial aid (www.ncaa.org). Consequently, the most accomplished athletes (e.g., fastest

307 sprinters) typically attend Division I institutions whereas the least accomplished generally attend

308 Division III institutions. NCAA institutions are almost entirely comprised of U.S. schools.

309 We searched for email addresses through each school's online directory and emailed all

310 whom we could. In cases where we could not find email addresses, we attempted to make contact

311 via Facebook. We were able to contact 72 of 114 candidate male sprinters (DI, $\mathrm{n}=57$; DII, $\mathrm{n}=$

312 38; DIII, $n=19$ ), and 72 of 146 female sprinters (DI, $n=59$; DII, $n=42$; DIII, $n=45$ ). Of those

313 contacted, 7 males (10\%) and 13 females (18\%) participated. In a similar manner, we attempted

314 to contact all male and female individual qualifiers for the championship meets in the shot put,

315 discus, and javelin throws. We were able to contact 83 of 159 male throwers (DI, $\mathrm{n}=68$; DII, $\mathrm{n}=$

31642 ; DIII, $\mathrm{n}=49$ ), and 107 of 169 female throwers (DI, $\mathrm{n}=63$; DII, $\mathrm{n}=47$; DIII, $\mathrm{n}=59$ ). Of those

317 contacted, 18 males (22\%) and 26 females (24\%) participated. Numbers of qualifying athletes in

318 each Division vary because some athletes qualified for multiple events and the number of athletes

319 that met each Division's championship qualifying standards varied.

320 The initial recruitment statement requested individuals to participate in a survey study of

321 the "Development of elite athletic ability." Individuals were informed that they had been

322 contacted because they had qualified for the 2012 NCAA Outdoor Track and Field

323 Championships. They were informed that the survey would take 5-10 min to complete and could

324 be accessed by following an embedded link. No incentives for participation were offered. We first 
325 solicited responses from athletes from 13-15 July 2012, and this yielded 35 responses; we

326 solicited responses again on 29 July 2012, and this yielded 29 additional responses.

\section{Survey}

328 The survey was implemented with the commercial platform, SurveyMonkey. It began with the

329 item, "To the best of your recollection, how would you compare your SPRINTING SPEED to

330 others your own age and gender when you were 6-10 years old?" Five choices were offered,

331 "much slower", "slower", “about the same", "faster", and "much faster". The next item was the

332 same except that the age range was 11-15 years old. Then, for each age range, there were similar

333 multiple-choice items addressing physical strength and overhand throwing ability. We chose these

334 age ranges because (a) 6-10 years constitutes a range before the typical onset of puberty and an

335 age range when children are in school and can compare their athletic abilities (e.g., sprinting and

336 throwing) with a larger group of peers than was available to them before attending school and (b)

337 11-15 years captures the onset of puberty [66] but is earlier than most elite sprinters in Studies 1

338 and 2 reported, or were reported, to have begun formal sprint training with coaches.

339 The survey also included the following items:

340 - "If you competed in any of the following individual events in your FIRST YEAR OF

341 HIGH SCHOOL track and field, please report your best performance in the event(s)

342 during this FIRST YEAR OF HIGH SCHOOL track and field." This was followed by

343 a list of all common track and field events and a text box for each.

344 - "How old were you or what grade were you in at the end of YOUR FIRST SEASON

$345 \quad$ OF HIGH SCHOOL track and field?"

346 - "To the best of your recollection, at what age (or grade) did you begin to seriously

347 concentrate on track and field? (By seriously concentrate, we mean giving much

348 attention and effort to training, usually with a coach.)" 
349 The questionnaire also included items addressing gender, age, receipt of athletic-related financial

350 aid, level of competition (e.g., Division I, II, or III), sports played prior to college besides track

351 and field, recollections of first timed race, and best lifetime performances in all track and field

352 events. No individually identifying information was sought, such as name or school.

\section{Normative data}

354 Normative data are required to assess the initial sprinting performance of elite sprinters. Because

355 surveys (see below) indicated that these sprinters generally began regular training in $9^{\text {th }}$ or $10^{\text {th }}$

356 grade (usually ages 14-16) and usually reported best times for their first high school season, we

357 focused on this age, and used two approaches to estimate normative data. First, we extrapolated

$358100 \mathrm{~m}, 200 \mathrm{~m}$, and $400 \mathrm{~m}$ times (standard distances in U.S. high school meets) from normative

359 values of $50 \mathrm{~m}$ times for a large representative sample of 15 year-old Australian schoolchildren

360 [67]. We used Australian data because we could not find data from the U.S., and we have no

361 reason to suspect that athletic abilities of the children from these nations differ substantially. We

362 multiplied normative $50 \mathrm{~m}$ times by 2 to obtain $100 \mathrm{~m}$ benchmarks and by 4 to obtain $200 \mathrm{~m}$

363 benchmarks; because even world class runners slow by at least $10 \%$ when running $400 \mathrm{~m}$, we

364 multiplied $50 \mathrm{~m}$ times by 8.8 to obtain $400 \mathrm{~m}$ benchmarks. Thus, for females, $50^{\text {th }}$ percentile

365 benchmarks were $17.2(100 \mathrm{~m}), 34.4(200 \mathrm{~m})$, and $75.7 \mathrm{~s}(400 \mathrm{~m}) ; 95^{\text {th }}$ percentile benchmarks

366 were $15.4,30.8$, and $67.8 \mathrm{~s}$. The corresponding benchmarks for males were 15.4, 30.8, and $67.8 \mathrm{~s}$

$367\left(50^{\text {th }}\right.$ percentile), and $14.0,28.0$, and $61.6 \mathrm{~s}\left(95^{\text {th }}\right.$ percentile) $\mathrm{sec}$.

368 This method of determining benchmarks is conservative because our examination of high

369 school data (see next paragraph) shows that children slow with increasing sprint distances even

370 for $100 \mathrm{~m}$ and $200 \mathrm{~m}$ distances. In other words, if we had used more realistic, but difficult to

371 determine, benchmarks, the high school performances of the collegiate sprinters would seem

372 even more exceptional. 
374 upper boundary of performance. We did this by documenting the fastest $100 \mathrm{~m}$ and $200 \mathrm{~m}$ times

375 recorded by $9^{\text {th }}$ or $10^{\text {th }}$ graders at high school divisional championship meets held in 2012 . To

376 obtain a reasonably representative sample, we first identified a website with track and field

377 results for most U.S. high schools (http://www.athletic.net/). We searched 10 U.S. states in

378 alphabetical order, looking for the first high school in alphabetical order in each state with results

379 from the 2012 season. We focused on this school's meet prior to the state championship meet,

380 which was generally called a conference, sectional or division meet. These meets included 4 to 16

381 teams (median $=9.5)$ and would be open to all or nearly all pupils at each school. The mean

382 school population $\left(9^{\text {th }}-12^{\text {th }}\right.$ grade $)$ at each divisional meet ranged in size from 280 to 2100

383 students $($ median $=1483)$. Thus, the fastest $9^{\text {th }}$ or $10^{\text {th }}$ grade performances would generally

384 represent the fastest male and female in a population of roughly 2,000 to 5,000 peers of the same

385 sex and age. The median fastest times among $9^{\text {th }}$ and $10^{\text {th }}$ grade female performers were 12.96 and

$38626.45 \mathrm{~s}$. For males, the median fastest times for $9^{\text {th }}$ and $10^{\text {th }}$ graders were 11.41 and $23.25 \mathrm{~s}$. We

387 consider these times to indicate performance at the $99^{\text {th }}$ percentile or greater. We did not include

388 median best $400 \mathrm{~m}$ times because many of these meets did not include a $9^{\text {th }}$ or $10^{\text {th }}$ grader among

389 their finalists.

\section{Results and Discussion}

391 Contrary to the DPM, collegiate sprinters recalled being faster relative to their peers than did

392 collegiate throwers (Table 3; Fig. 2). This difference was significant and substantial for

393 recollections of 6-10 and 11-15 years of age, and the differences held within men and women

394 (Table 3). In fact, 90\% of sprinters reported they were faster or much faster than their peers at 6-

39510 years of age and $80 \%$ reported they were faster or much faster at 11-15 years of age. As we

396 predicted, throwers recalled being stronger and having better overhand throwing ability relative

397 to their peers than did sprinters, and these differences held robustly for both age ranges and 
398 within men and women (Table 3). These results corroborate Studies 1 and 2 by showing that

399 expert sprinters consistently recalled being faster than their peers as children. Furthermore, these

400 recollections were at least somewhat specific to sprinting and so cannot be dismissed as a

401 manifestation of general athletic ability.

402 Table 4 provides information for each sprinter regarding their background, onset of

403 training, and best performances. Seventeen of 20 sprinters reported at least one best performance

404 in their first season of high school competition, and only two of these reported they had begun

405 serious training prior to this. Of the 15 sprinters who reported first season high school

406 performances and no prior serious training, 13 of 15 were age 15 or younger at the end of this

407 first season, supporting our decisions regarding age-appropriate benchmarks (see Methods). All

40827 performances recalled by these 15 sprinters were faster than $95^{\text {th }}$ percentile benchmarks.

409 Moreover, seven of these sprinters recalled at least one performance faster than the $99^{\text {th }}$ percentile

410 benchmarks, and two of the others recalled performances that were within $0.5 \mathrm{~s}$ of $99^{\text {th }}$ percentile

411 benchmarks. These results represent more objective evidence that, relative to their peers, these

412 sprinters were exceptional prior to the accumulation of substantial training.

413 A possible limitation of Study 3 is that the response rate of college athletes was low.

414 However, a low response rate is reasonable because we did not provide athletes with incentives to

415 participate and because we attempted to contact them after the academic year had ended. More

416 importantly, to minimize response bias, we constructed the survey questions to appear neutral to

417 the DPM or the "talent matters" framework.

\section{General Discussion}

419 The three studies of sprinter development in this paper focused on testing two crucial predictions

420 of the DPM. We begin our discussion by considering each prediction. We then examine the

421 implications of our findings.

\section{Elite sprinters are initially remarkable}


423 The first DPM prediction is that elite sprinters should have generally been unremarkable prior to

424 training. Contrary to this, the biographical materials examined in Studies 1 and 2 indicated

425 exceptional initial ability for all 26 world class sprinters for whom we were able to obtain

426 relevant information. Study 3 corroborated this pattern in national qualifying collegiate sprinters,

427 showing that they recalled being faster or much faster than their peers as children. In addition,

428 these collegiate sprinters reported achieving performances in their first season of high school

429 competition that would have exceeded $95-99 \%$ of their peers despite the fact that most had begun

430 formal training that same season.

431 A limitation of these studies is that the use of biographical materials relies on the

432 retrospective recall of information from many years earlier, and this information may be

433 inaccurate or biased [68], although studies have demonstrated moderately high correlations

434 between information obtained by retrospective recall and that found by examining diaries $[3,69$ -

435 71]. Most empirical studies addressing the DPM framework use systematic methods, such as

436 requiring participants to maintain regular training diaries $[3,69,70,72]$. Such studies have not

437 been conducted for sprinting, and they seem impractical. This is because, to our knowledge, there

438 are no formal training programs or sports academies that endeavor to train "typical" children or

439 adolescents so that they develop into elite sprinters. Apparently formal, dedicated sprint training

440 is only taken up by individuals who are recognized as being exceptionally fast prior to formal

441 training.

442 We also note that there are several reasons why inaccurate or biased biographical

443 materials cannot provide a satisfying explanation for our results. First, if many sprinters in

444 Studies 1 and 2 were not exceptionally fast prior to formal training, it would seem that at least

445 some coaches, competitors, or peers would attempt to report the truth to biographers and

446 journalists. For example, if Gwen Torrence and Evelyn Ashford had not, as untrained high school

447 students, each beaten their school's star (male) football player in a race, as their biographies 
448 attested [73,74], we might have expected someone to dispute these or the many similar claims in

449 other biographies. Similarly, most biographical accounts of extraordinary youth sprinting ability

450 are corroborated by publicly documented timed performances. Moreover, objective facts such as

451 race results are more accurately recalled than are subjective states (e.g., recalling the amount of

452 effort put into a particular practice session) [75].

453 A second point is that Study 3, based on national qualifying collegiate sprinters, fully

454 corroborated Studies 1 and 2. Although it was based on self-reports, the responses were

455 anonymous, and this should have minimized self-presentation bias that might have occurred in

456 the biographies (e.g., champion sprinters desiring to portray themselves as being innately gifted.)

457 A final point is that DPM proponents have used biographical materials similar to ours to

458 support their key claims. Most notably, Ericsson et al. [3] and Howe et al. [6] reviewed

459 biographies and retrospective studies of a variety of eventual experts (e.g., musicians, painters,

460 chess players) and argued that these indicate that the experts' initial performances were

461 consistently unexceptional and that many years of deliberate practice always preceded their

462 emergence as experts. Studies 1 and 2 demonstrate beyond doubt that this pattern does not hold

463 for the biographies of most (and perhaps all) expert sprinters. There is no reason to dismiss

464 sprinters' biographies as highly inaccurate or biased while accepting the veracity of other

465 biographies.

466 Our studies are also notable because they ruled out two alternative explanations for

467 sprinters' initially exceptional abilities. In Study 1 we addressed the transfer hypothesis, whereby

468 remarkable initial performance in one domain, such as sprinting, might be due to previous

469 training in another, such as football or baseball [6]. We showed that a transfer hypothesis is not

470 viable because the biographies of Olympic champions revealed that two-thirds of them did not

471 participate in organized sports prior to beginning sprinting. A DPM proponent might protest that

472 perhaps informal sports participation was crucial for sprinting development. This argument has 
473 some validity: informal (and difficult to measure) experience (e.g., play) might be crucial.

474 However, accepting this argument would still entail abandoning the underlying premise of the

475 DPM, that expertise must be based on formal, deliberate training.

476 With Study 3 we addressed the possibility that remarkable initial sprinting ability might

477 be merely indicative of unusual general athletic ability or early physical maturation. Contrary to

478 this, the collegiate sprinters generally recalled being faster or much faster than their peers as

479 children, whereas another group of similarly elite athletes, throwers, did not recall being as

480 exceptionally fast. That the opposite pattern occurred for physical strength and overhand

481 throwing shows that sprinting ability is not merely a manifestation of general athletic ability; it is

482 specific, at least to some extent, consistent with definitions of talent [6]. As we will discuss

483 below, however, speed is crucial for many other sports so it is not surprising that many champion

484 sprinters excelled in sports besides track and field.

There are other possible concerns about our tests of this prediction, but none seem

compelling. One concern is that, although we found evidence of initially outstanding speed in all

487 three studies, the sample sizes were modest (i.e., $\mathrm{n}=26$ for Studies 1 and 2 combined; $\mathrm{n}=20$

488 sprinters for Study 3). This does not seem like a major weakness, however, because genuine

489 experts are, by definition, rare, which is why many DPM studies use modest samples. For

490 example, the seminal paper by Ericsson and colleagues [3] included data from only 54 musicians,

491 only 22 of whom were considered expert.

A second, related concern is that our results are based on expert sprinters and perhaps may

493 not apply to the development of sprinting abilities in a general population of athletes. In other

494 words, for most athletes initial performance might explain little or no variation in the attainment

495 of sprinting ability. This point is largely valid: studies of the initial performance and development

496 of sprinting ability with proper training in broad range of individuals are certainly desirable.

497 Nonetheless, this point does not mitigate the challenge our results pose to the DPM. This is 
498

499

500 is no meaningful distinction (e.g., talent) between expert and non-experts besides in their training

$501[3,6]$. In addition, we note that Study 3 included many athletes whose best performances to date

502 are far from world class (Table 4); given the base rate occurrence of world class performances

503 and the typical patterns of world class sprinter development (Figure S1), most of these sprinters

504 never will achieve world class performances. Nonetheless, their initial performances in childhood

505 and high school were generally outstanding. This indicates that the patterns we documented do

506 occur generally.

\section{Elite sprinters break the "10 year rule"}

508 Our studies also contradict the DPM's prediction that at least 10 years of deliberate practice are

509 necessary to achieve expert level performance. The results of Study 1 showed this because the child begins training at age 10 and reaches world class status at age 20 , one interpretation is that

52210 years of deliberate practice were necessary for this improvement. An alternative interpretation 
523 is that elite performance can only occur after physical maturation and that a talented individual

524 could have reached the same performance level at age 20 if they had only begun training at age

525 18. Although this might seem far-fetched, in the course of our research we discovered two

526 documented cases of men beginning formal sprint training as adults and reaching world class

527 status within one year. The athletic biographies of these sprinters, Dave Sime and Delano

528 Meriwether, are impossible to reconcile with the DPM, and we have summarized their

529 biographies in Table S3.

530 Moreover, the biographies of Sime and Meriwether patently contradict the DPM's claim

531 that an athlete who starts deliberate practice at a relatively late age would not be able to "catch

532 up" to an athlete who started training earlier [4,77] and the complementary view that extensive

533 experience in a sport is necessary to reach world class status [12]. We also note that rapid

534 development of sprinting expertise was not limited to men. Female Olympic gold medal winners

535 Helen Stephens, Wilma Rudolph, Evelyn Ashford, and Marion Jones all achieved world class

536 sprinting status within three years of beginning training (Table 1).

537 DPM proponents might argue that achieving expertise in less than 10 years might reflect

538 extraordinarily intense training, so that, in a sense, 10 years of training might be compressed into

539 nine (or fewer) years. However, the biographies of world class sprinters do not fit the claim of

540 unusually intensive training (see Table S2). For example, Usain Bolt's biographies [78,79],

541 including his autobiography [52], document that his often extreme disinterest in training has been

542 very frustrating for his coaches. In fact, Bolt was left off of the Jamaican national team

543 competing at the 2003 IAAF World Championships because of his lackadaisical attitude [78].

544 We also note that sprint training requires high intensity efforts on the track and in the

545 weight room several days per week with the remaining days spent in rest and low intensity

546 recovery exercises [50,80-82]. Even Ericsson et al. [3] and Ericsson [83] recognized that very

547 intensive sprint training is difficult for long periods even with periods of rest. Consequently, the 
548 time that sprinters spend practicing sprinting may be very brief. For example, Carl Lewis,

549 considered by many to be the paragon of professionalism as a track and field athlete, reported that

550 a typical sprint training session consisted of sprinting $200 \mathrm{~m}$ six times averaging $23.0 \mathrm{~s}$ for $200 \mathrm{~m}$

551 with one minute of rest between sprints [84]. Keith Roberts, Grand Valley State University’s

552 sprint coach, (pers. comm.) estimates that collegiate and professional sprinters typically spend

$553600-700 \mathrm{hr}$ per year training on the track and in the weight room combined and that high school

554 sprinters would typically spend considerably less time. At the professional rate, it would take

555 between 14 and 17 years to accumulate $10,000 \mathrm{hr}$ of deliberate practice.

556 The DPM has been falsified for sprinting

557 Is there any way to reconcile our results with the DPM? We do not think there is. As reviewed

558 here, several lines of evidence contradict the DPM, and even the data that seem consistent with it

559 (e.g., some sprinters "needing" ten years of deliberate practice) are easily accommodated into the

560 "talent matters" framework. Furthermore, in our review of biographical materials and discussions

561 with coaches and experts, we did not encounter even one account of an elite sprinter that

562 prototypically fits the DPM (e.g., a sprinter who was mediocre compared to a general population

563 of their peers and who engaged in deliberate practice for many years and eventually became

564 elite). The absence of such accounts, together with the data in our three studies and many

565 complementary physiological and genetic studies [32,85,86], allow us to conclude with

566 confidence that the DPM has been falsified in the domain of sprinting.

567 Sprinting is an authentic expertise domain

568 Although the evidence indicates that the DPM has been falsified for sprinting, it might be argued

569 that this does not seriously weaken the model because sprinting is an inauthentic or highly

570 unusual expertise domain. One version of this argument is that sprinting is inauthentic because

571 performances are highly constrained in that the goal is the same for every performance, to run as

572 fast as possible. By contrast, prototypical domains, such as chess or music, demand far greater 
573 flexibility in decision-making and/or motor skills. This argument is unconvincing, however,

574 because DPM researchers have frequently assumed the relevance of other highly constrained

575 domains. For instance, Ericsson et al. [3] discussed how unremarkable adults can be trained to

576 achieve prodigious performance in specific memory tasks, and Ericsson et al. [5] noted that, with

577 proper training, otherwise unremarkable adults can greatly improve their endurance running or

578 complete thousands of pushups per day. Thus, it seems likely that if DPM proponents could

579 demonstrate that most healthy adolescents can achieve outstanding sprint performances (e.g., $<$

$58011.5 \mathrm{~s}$ for $100 \mathrm{~m}$; see Study 2 and Table 3 ) with only a few months of deliberate practice, they

581 would do so and cite this as evidence supporting the DPM. The fact that such a demonstration is

582 apparently impossible must, therefore, count against the DPM.

583 A second possible argument is that sprinting is an inauthentic domain because it requires

584 minimal skill. In other words, one might be dazzled by a professional pianist while dismissing a

585 world class sprint performance as something that almost anyone could achieve, albeit more

586 slowly. This argument is also unpersuasive because sprinting does require skill. Elite sprinters

587 exert much effort in physical training (e.g., running, plyometrics, strength training) and technique

588 (e.g., starts, transitions) [50,80-82]. The resulting improvements may be modest (e.g., 1-6\%; see

589 Table 2), yet they can easily make the difference between being a mere qualifier for a

590 championship meet and being the champion.

591 We also note that sprinting is one of the most popular sports across a broad spectrum of

592 traditional and modern societies [87-91]. Sprinting's popularity is also revealed by the global

593 fame accorded to Olympic champions such as Jesse Owens [92], Wilma Rudolph [93], Bob

594 Hayes [53], Marion Jones [54], and Usain Bolt [52]. Furthermore, unlike prototypical expertise

595 domains (e.g., music, chess), no special equipment is needed for sprinting, meaning that, in most

596 societies, it can be undertaken by virtually any individual. These points suggest that sprinting is

597 not merely an authentic expertise domain; it may be an ideal one. 
599 decision-making or cognitive skills, could be substantially different than for sprinting and other

600 domains of physical skill [21]. Nonetheless, there is mounting evidence that much individual

601 variation in achievement in more cognitive expertise domains (e.g., music, chess, educational

602 attainment) also cannot be accounted for by the DPM [27,30,31,36,94].

603 Sprinting is a foundational expertise domain

604 We have argued that our results pose intractable problems for the DPM. However, the

605 implications of these results are actually greater than showing that one authentic domain does not

606 fit the model. This is because sprinting is a foundational domain in the sense that elite speed is

607 necessary or at least highly advantageous in many other sports. Coaches and commentators

608 frequently convey this in asserting that "speed kills" and much research supports the point

$609[95,96]$. For example, in American football, sprinting speed over 40 yards is a significant

610 predictor of playing ability and highly recruited high school players often possess similar speed

611 to professionals [97].

612 The advantages of superior sprinting speed are particularly well illustrated in cases where

613 elite sprinters take up new sports and reach world class status soon thereafter. For example, an

614 Australian woman recruited to train for skeleton, a winter sliding sport, based on her $30 \mathrm{~m}$

615 sprinting speed reached world class status after only ten weeks of sport-specific training [98].

616 More recently, two American world class sprinters, Lolo Jones and Lauryn Williams, rapidly

617 made the transition to world class bobsled competition. Within several months of taking up the

618 sport, Jones helped the U.S. team win a world championship (http://sportsillustrated.cnn.com/

619 more/news/20130228/lolo-jones-bobsled.ap/). Two years after beginning bobsled training, Jones

620 was named to the 2014 U. S. Winter Olympics team. Her teammate Lauryn Williams, a 2012

621 Olympic gold medalist sprinter in the $4 \times 100 \mathrm{~m}$ relay, was named to the 2014 Olympic bobsled

622 team six months after beginning training (http://lauryn-williams.com/). 
623 We also note that while this paper has focused on behavioral data revealing the existence

624 of innate sprinting talent, complementary studies have implicated genetic and physiological

625 mechanisms $[85,99]$. Studies using similar methods have indicated that characteristics crucial to

626 success in other sports are also partly innate. For example, substantial heritability has been

627 demonstrated for muscle mass and strength, critical contributors to success in power sports (e.g.,

628 American football, weightlifting) $[100,101]$ and for untrained $\mathrm{VO}_{2}$ max and $\mathrm{VO}_{2}$ max

629 responsiveness, which are vital for endurance sports [32,33]. The convergence of this evidence

630 suggests sprinting speed is only one of several innate ingredients that, depending on the particular

631 sport, may be crucial for success. 


\section{Concluding remarks}

633 Our studies are the first to systematically show that: (1) a strong predictor, probably a

634 precondition, for elite sprinting performance is exceptional speed prior to formal training, (2) this

635 exceptional ability is at least partly specific to sprinting, and (3) many elite sprinters reach world

636 class status in far less than 10 years, although they usually make modest improvements even after

637 that (Figure S1). Although these results are novel in the scientific literature, it is striking how

638 closely they seem to correspond with folk wisdom or commonsense. In fact, in conversations

639 about this research with colleagues, we found that everyone with at least some athletic experience

640 anticipated our main findings.

641 Thus, the previous neglect of sprinting in the context of the DPM seems puzzling. On the

642 one hand, it would seem that those skeptical of the DPM would have pointed out that sprinting

643 strongly challenges it. The fact that they did not perhaps reveals the success of DPM proponents

644 in steering research towards domains where the DPM is more difficult to rule out. On the other

645 hand, the fact that DPM proponents neglected sprinting seems understandable: people are

646 notorious for overlooking or discounting evidence that contradicts their views $[102,103]$.

647 Finally, we find remarkable the continued popularity of the DPM despite its empirical

648 weaknesses and theoretical implausibility $[21,27,28,34,104]$. We speculate that the model's

649 popularity reflects a more general desire to adhere to a "Blank Slate" view of human nature,

650 whereby behavior is wholly shaped by the environment and that individuals have no inborn

651 predispositions or talents besides the general ability to learn [1,105]. Although contradicted by

652 evolutionary theory and abundant empirical data, the Blank Slate remains popular, apparently

653 because of its supposed benevolent consequences (e.g., that anyone can achieve expertise)

$654[1,104]$.

655 However, the Blank Slate view can have negative impacts as well. As an example, 656 imagine that a youngster expressed a strong passion to become a world class sprinter and they 
657 trained with great dedication under expert coaches for 10 years. Our studies indicate that, despite

658 this training, the individual will not realize or even approach their goal unless they happen to

659 possess extraordinary talent. The DPM view, by contrast, logically implies that their inability to

660 become world class must be solely due to training failures on the part of the individual or their

661 coaches. We believe that such blame would be unwarranted and undesirable and that a realistic

662 view — that both training and talent are necessary — is preferable.

\section{Acknowledgements}

664 We benefited from conversations with Rick Albrecht and John Kilbourne and the GVSU track

665 and field coaches, especially Jerry Baltes, Blaine Maag, and Keith Roberts. Brian Gurta helped in

666 the initial stages of data collection. Shadie Emiah helped find contact information for collegiate

667 athletes. Walt Murphy provided important biographical information about sprinters. Zach

668 Hambrick, Shane Mueller, Ross Tucker, Bo Winegard, and Mike Wolfe provided useful

669 comments on previous versions of the manuscript as did two anonymous reviewers.

\section{REFERENCES}

671 1. Pinker S (2002) The blank slate: the modern denial of human nature. New York, NY:

$672 \quad$ Viking.

673 2. Ridley M (2003) Nature via nurture: genes, experience, and what makes us human. New

$674 \quad$ York, NY: HarperCollins Publishers.

675 3. Ericsson KA, Krampe RT, Tesch-Römer C (1993) The role of deliberate practice in the

676 acquisition of expert performance. Psychol Rev 100: 363-406.

677 4. Ericsson KA, Prietula MJ, Cokely ET (2007) The making of an expert. Harvard Bus Rev

$678 \quad$ July-August: $1-8$.

679 5. Ericsson KA, Nandagopal K, Roring RW (2009) Toward a science of expceptional

680 performance. Attaining superior performance through deliberate practice. Ann NY Acad Sci

$681 \quad 1172: 199-217$. 
682 6. Howe MJ, Davidson JW, Sloboda JA (1998) Innate talents: reality or myth? Behav Brain 683 Sci 21: 399-442.

684 7. Visscher PM (2008) Sizing up human height variation. Nat Genet 40: 489-490.

685 8. Livshits G, Roset A, Yakovenko K, Trofimov S, Kobyliansky E (2002) Genetics of human 686 body size and shape: body proportions and indices. Ann Hum Biol 29: 271-289.

687 9. Baker J, Côte J, Abernathy B (2003) Learning from the experts: practice activities of expert 688 decision makers in sport. Res Q Exerc Sport 74: 342-347.

689 10. Gagné F (2009) Debating giftness: pronat vs. anitnat. In: Shavinina LV, editor. International 690 handbook on giftedness. New York, NY: Springer Science+Business Media B. V. pp. $155-$ 691204

692 11. Starkes JL, Deakin JM, Allard F, Hodges NJ, Hayes A (1996) Deliberate practice in sports: 693 what is it anyway? In: Ericsson KA, editor. The road to excellence: the acquisition of expert 694 performance in the arts, sciences, sports and games. Mahwah, NJ: Erlbaum. pp. 81-106.

695 12. Williams MA, Ford PR (2008) Expertise and expert performance in sport. Int R Sport Exerc $696 \quad$ Psychol 1: 4-18.

697 13. Coyle D (2009) The talent code: Greatness isn't born, It's grown. Here's how. New York, $698 \quad$ NY: Bantam Dell.

699 14. Gladwell M (2008) Outliers. New York, NY: Little, Brown and Company.

700 15. Syed M (2010) Bounce: the myth of talent and the power of practice. New York, NY: $701 \quad$ HarperCollins Publ.

702 16. Plomin R, DeFries JC, McLearn GE, McGuffin P (2008) Behavioral genetics. New York, $703 \quad$ NY: Worth Publishers.

704 17. Ebstein RP, Israel S, Chew SH, Zhong S, Knafo A (2010) Genetics of human social 705 behavior. Neuron 65: 831-844.

706 18. Collins M (2009) Genetics and sports. Basel, Switzerland: Karger. 
707 19. Timmons JA, Knudsen S, Rankinen T, Koch LG, Sarzynski M et al. (2010) Using

708 molecular classification to predict gains in maximal aerobic capacity following endurance

$709 \quad$ exercise training in humans. J Appl Physiol 108: 1487-1496.

710 20. Hagberg JM, Rankinen T, Loos RJF, Perusse L, Roth SM et al. (2011) Advances in exercise,

711 fitness, and performance genomics in 2010. Med Sci Sports Exerc 43: 743-752.

712 21. Abernethy B, Farrow D, Berry J (2003) Constraints and issues in the development of a

713 general theory of expert perceptual-motor performance. In: Starkes JL, Ericsson KA,

714 editors. Expert performance in sports: advances in research on sport expertise. Champaign,

$715 \quad$ IL: Human Kinetics. pp. 349-369.

716 22. Deaner RO (2013) Distance running as an ideal domain for showing a sex difference in 717 competitiveness. Arch Sex Behav 42: 413-428.

718 23. de Block A, Dewitte S (2009) Darwinism and the cultural evolution of sports. Perspect Biol $719 \quad$ Med 52: 1-16.

720 24. Lombardo MP (2012) On the evolution of sport. Evol Psychol 10: 1-28.

721 25. Miller G (2000) The mating mind. New York, NY: Anchor Books.

722 26. Hawkes K, Bird RB (2002) Showing off, handicap signaling, and the evolution of men's

$723 \quad$ work. Evol Anthropol 11: 58-67.

724 27. Hambrick DZ, Meinz EJ (2011) Limits on the predictive power of domain-specific

725 experience and knowledge in skilled performance. Curr Dir Psychol Sci 20: 275-279.

726 28. Tucker R, Collins M (2012) What makes champions? A review of the relative contribution

727 of genes and training to sporting success. Brit J Sports Med 46: 555-561.

728 29. Kremen WS, Jacobsen KC, Xian H, Eisen SA, Eaves LJ et al. (2007) Genetics of verbal

729 working memory processes: A twin study of middle-aged men. Neuropsychol 21: 569-580.

730 30. Meinz EJ, Hambrick DZ, Hawkins CB, Gillings AK, Meyer BE et al. (2011) Roles of

731 domain knowledge and working memory capacity in components of skill in Texas hold'em 
732 poker. J Appl Res Memory Cognition 1: 34-40.

733 31. Meinz EJ, Hambrick DZ (2010) Deliberate practice is necessary but not sufficient to

734 explain individual differences in piano sight-reading skill: the role of working memory

735 capacity. Psychol Sci 21: 914-919.

736 32. Bouchard C, Sarzynski MA, Rice TK, Kraus WE, Church TS et al. (2011) Genomic

737 predictors of maximal O2 uptake response to standard exercise training programs. J Appl

$738 \quad$ Physiol 110: 1160-1170.

739 33. Bouchard C, Blair SN, Church TS, Earnest CP, Hagberg JM et al. (2012) Adverse metabolic

740 response to regular exercise: is it a rare or common occurrence? PLOS ONE

741 doi:10.1371/journal.pone.0037887.

742 34. Ackerman PL (2013) Nonsense, common sense, and science of expert performance: talent

743 and individual differences. Intelligence doi.org/10.1016/j.intell.2013.04.009.

744 35. Ruthsatz J, Detterman D, Griscom WS, Cirullo BA (2008) Becoming an expert in the

745 musical domain: It takes more than just practice. Intelligence 36:330-338.

746 36. Hambrick DZ, Oswald FL, Altmann EM, Meinz EJ, Gobet F et al. (2013) Deliberate

747 practice: Is that all it takes to become an expert? Intelligence Available:

$748 \quad$ http:dx.doi.org/10.1016/j.intell.2013.04.001 via the Internet.

749 37. Duffey LJ, Baluch B, Ericsson KA (2004) Dart performance as a function of facets of

750 practice amongst professional and amateur men ana women players. Int J Sport Psychol 35:

$751 \quad 232-245$.

752 38. Gobet F, Campitelli G (2007) The role of domain-specific practice, handedness, and starting 753 age in chess. Dev Psychol 43: 159-172.

754 39. Oldenziel K, Gagne F, Gulbin J (2004) Factors affecting the rate of athletic development

755 from novice to senior elite: how applicable is the 10-year rule? Available:

756 http:/cev.org.bc/biblioteca/factors-affecting-the-rate-of-athlete-development-from-novice- 
to-senior-elite-how-applicable-is-the-10-year-rule via the Internet.

758

759

760

761

762

763

764

765

766

767

768

769

770

771

772

773

774

775

776

777

778

779

780

781

40. Ericsson KA (2013) Training history, deliberate practise and elite sports performance: an analysis in response to Tucker and Collins review-what makes champions? Brit J Sports Med 47: 533-535.

41. Kalinowski AG (1985) The development of Olympic swimmers. In: Bloom BS, editor. Developing talent in young people. New York, NY: Ballantine. pp. 139-192.

42. Wallingford R (1975) Long distance running. In: Taylor AW, Landry F, editors. The scientific aspects of sports training. Springfield, IL: Charles C. Thomas. pp. 118-130.

43. Monsaas JA (1985) Learning to be a world-class tennis player. In: Bloom BS, editor. Developing talent in young people. New York, NY: Ballantine. pp. 211-269.

44. Helsen WF, Starkes JL, Hodges NJ (1998) Team sports and the theory of deliberate practice. J Sport Exerc Psychol 20: 12-34.

45. Hodges NJ, Starkes JL (1996) Wrestling with the nature of expertise: a sport-specific test of Ericsson, Krampe, and Tesch-Romer's (1993) theory of “deliberate practice". Int J Sport Psychol 27: 400-424.

46. Young BW, Salmela JH (2002) Perceptions of training and deliberate practice of middle distance runners. Int J Sport Psychol 33: 167-181.

47. Cobley S, Baker J, Wattie N, McKenna J (2009) Annual age-grouping and athlete development. Sports Med 39: 235-256.

48. Baker J, Côte J, Abernathy B (2003) Sport-specific practice and the development of expert decision-making in team ball sports. J Appl Sports Psychol 15: 12-25.

49. Smeeton NJ, Ward P, Williams AM (2004) Do pattern recognition skills transfer across sports? A preliminary analysis. J Sports Sci 22: 205-213.

50. Francis C, Coplon J (1991) Speed trap: inside the biggest scandal in Olympic history. New York, NY: St. Martin's Press. 
782 51. Moore R (2012) The dirtiest race in history: Ben Johnson, Carl Lewis and the Olympic

783 100m final (Wisden Sports Writing). London, UK: A\&C Black.

784 52. Bolt U (2010) Usain Bolt: my story: 9.58: being the world's fastest man. London, UK:

$785 \quad$ HarperSport.

786 53. Hayes B (1990) Run, bullet, run: the rise, fall, and recovery of Bob Hayes. New York, NY:

$787 \quad$ Harper \& Row.

788 54. Jones M (2004) Life in the fast lane. New York, NY: Time Warner Books.

789 55. Smith T, Steele D (2007) Silent gesture: the autobiography of Tommie Smith. Philadelphia,

$790 \quad$ PA: Temple University Press.

791 56. Seiler S, DeKoning JJ, Foster C (2007) The fall and rise of the gender difference in elite

792 anaerobic performance 1952-2006. Med Sci Sports Exerc 39: 534-540.

793 57. Lawson G (1997) World record breakers in track \& field athletics. Champaign, IL: Human $794 \quad$ Kinetics.

795 58. Hollobaugh J (1991) T\&FN interview: Leroy Burrell. Track \& Field News 56-57.

796 59. Satterfield L (1997) It's full speed ahead for Williams track: Carver's Bernard Williams

797 uses his past struggles to motivate himself to be better - and faster. Baltimore Sun

798 onlineAvailable: http://articles.baltimoresun.com/1997-04-

799 13/sports/1997103063_1_bernard-williams-carver-williams-track via the Internet.

800 60. Lewis C, Marx J (1990) Inside track: my professional life in amateur track and field.

$801 \quad$ Toronto: Fireside Book.

802 61. Landman B (2008) Walter Dix sprints toward Olympics, greatness. Tampa Bay Times 17

$803 \quad$ July.

804 62. Ungerleider S (2001) Faust's gold: inside the East German doping machine. New York, NY:

805 Thomas Dunne Books.

806 63. Yesalis CE, Courson SP, Wright JE (2000) History of anabolic steroid use in sport and 
exercise. In: Yesalis CE, editor. Anabolic steroids in sport and exercise. Champaign, IL:

$808 \quad$ Human Kinetics. pp. 51-71.

809 64. Nooden M (1989) A dirty coach comes clean. Sports Illustrated 70: 22-23.

810 65. Axon R (2013) Tim Montgomery, former fastest man, up an running. USA Today Online

811 Available: http:/www.usatoday.com/story/sports/olympics/2013/09/10/tim-montgomery-

812 100-meter-world-record-prison/2795863 via the Internet.

813 66. Jones RE, Lopez KH (2006) Human reproductive biology. New York, New York: Academic $814 \quad$ Press.

815 67. Catley MJ, Tomkinson GR (2013) Normative health-related fitness values for children: 816 analysis of 85347 test results on 9-17-year-old Australians since 1985. Brit J Sports Med $817 \quad 47: 98-108$.

818 68. Shiffman S, Hufford M, Hickcox M, Paty JA, Gynys M et al. (1997) Remember that? A 819 comparison of real-time versus retrospective recall of smoking lapses. J Consult Clin $820 \quad$ Psychol 65: 292-300.

821 69. Sloboda JA, Davidson JW, Howe MJA, Moore DC (1996) The role of practice in the 822 development of performing musicians. Brit J Psychol 87: 287-304.

823 70. Baker J, Côte J, Deakin J (2005) Expertise in ultra-endurance triathletes early sport 824 involvement, training structure, and the theory of deliberate practice. J Appl Sport Psychol $825 \quad 17: 64-78$.

826 71. Ward P, Hodges NJ, Starkes JL, Williams AM (2007) The road to excellence: deliberate 827 practice and the development of expertise. High Ability Studies 18: 119-153.

828 72. Hodges NJ, Kerr T, Starkes JL, Weir PL, Nananidou A (2004) Predicting performance times

829 from deliberate practice hours for triathletes and swimmers: what, when, and where is $830 \quad$ practice important? J Exp Psychol-Appl 10: 219-237.

831 73. Hornbuckle AR (1995) Gwen Torrence. In: Porter DL, editor. African-American sports 
832 greats: a biographical dictionary. Westport, CT: Greenwood Press. pp. 358-361.

833 74. Davis MD (1992) Black American women in Olympic track and field. Jefferson, NC:

834 McFarland \& Company, Inc., Publishers.

835 75. Brewer WF (1998) Memory for randomly sampled autobiographical events. In: Neisser U,

836 Winograd E, editors. Remembering reconsidered: ecological and traditional approaches to

837 the study of memory. New York, NY: Cambridge University Press. pp. 21-90.

838 76. Bloom BS (1985) Developing talent in young people. New York, NY: Ballantine.

839 77. Baker J, Cobley S, Fraser-Thomas J (2009) What do we know about early sport

$840 \quad$ specialization? Not much! High Ability Studies 20: 77-89.

841 78. Cantor G (2011) Usain Bolt. Detroit, MI: Lucent Books.

842 79. Irving R (2010) Usain Bolt: phenomenal track athlete. In: Irving R, Charlton V, editors.

843 Jamaican gold: Jamaican sprinters. Kingston, Jamaica: University of the West Indies Press.

$844 \quad$ pp. $54-59$.

845 80. Ward RD, Dintiman GB (2003) Sports speed. Champaign, IL: Human Kinetics.

846 81. Smith M (2005) High performance sprinting. Wiltshie, UK: Crowood Press, Ltd.

847 82. Edwards J (2012) Research in sprinting: what science says about sprinting. New York, NY:

$848 \quad$ New American Press.

849 83. Ericsson KA (2006) The influence of experience and deliberate practice on the development

850 of superior expert performance. In: Ericsson KA, Charness N, Feltovich PJ, Hoffman DJ,

851 editors. The Cambridge handbook of expertise and expert performance. New York, NY:

852 Cambridge University Press. pp. 683-703.

853 84. Hurst M (1994) T\&FN interview: Carl Lewis. Track \& Field News 56-62.

854 85. Costill DL, Fink WJ, Pollock ML (1976) Muscle fiber composition and enzyme activities of 855 elite distance runners. Med Sci Sports 8: 96-100. 
856 86. Ahmetov II, Fedotovskaya ON (2012) Sports genomics: current state of knowledge and

857 future directions. Cellular Mol Exerc Physiol doi:10.7457/cmep.v1i1.11.

858 87. Deaner RO, Smith BA (2013) Sex differences in sports across 50 societies. Cross-Cult Res

$859 \quad 47: 268-309$.

860 88. Gotaas T (2009) Running: a global history. London, UK: Reaktion Books.

861 89. Guttmann A (2004) From ritual to record: the nature of modern sports. Updated with new

862 afterword. New York, NY: Columbia University Press.

863 90. Guttmann A (2004) Sports: the first five millennia. Amherst, MA: University of

$864 \quad$ Massachusetts Press.

865 91. Sears ES (2001) Running through the ages. Jefferson, NC: McFarland \& Company, Inc.,

$866 \quad$ Publ.

867 92. Baker WJ (1986) Jesse Owens: an American life. New York, NY: Free Press.

868 93. Smith MM (2006) Wilma Rudolph: a biography. Westport, CT: Greenwood Press.

869 94. Wai J (2013) Experts are born, then made: combining prospective and retrospective

870 longitudinal data shows that cognitive ability matters. Intelligence Available:

871 http://dx.doi.org/10/1016/j.intell.2013.08.009 via the Internet.

872 95. Huijgen BCH, Elferink-Gemser MT, Post WJ, Visscher C (2009) Soccer skill development

873 in professionals. Int J Sports Med 30: 585-591.

874 96. Little T, Williams AG (2005) Specificity of acceleration, maximum speed, and agility in 875 professional soccer players. J Strength Cond Res 19: 76-78.

876 97. Ghigiarelli JJ (2011) Combine performance descriptors and predictors of recruit rankings

877 for the top high school football recruits from 2001 to 2009: difference between position

878 groups. J Strength Cond Res 25: 1193-1203.

879 98. Bullock N, Gulbin JP, Martin DT, Ross A, Holland T et al. (2009) Talent identification and 880 deliberate programming in skeleton: ice novice to Winter Olympian in 14 months. J Sports 
Sci 27: 397-404.

882 99. Macarthur D, Yang N, Seto J, Raftery J, Kee A et al. (2006) A gene for speed: the ACTN3 883 R577X polymorphism influences muscle performance. Neuromuscular Disord 16: S59-S59.

884 100. Silventoinen K, Magnusson PKE, Tynelius P, Kaprio J, Rasmussen F (2008) Heritability of 885 body size and muscle strength in young adulthood: a study of one million Swedish men. $886 \quad$ Genet Epidemiol 32: 341-349.

887 101. Stewart CE, Rittweger J (2006) Adaptive processes in skeletal muscle: molecular regulators 888 and genetic influences. J Musculoskelet Neuronal Int 6: 73-86.

889 102. Lord CG, Ross L, Lepper MR (1979) Biased assimilation and attitude polarization: The 890 effects of prior theories on subsequently considered evidence. J Person Soc Psychol 37:

$891 \quad 2098-2109$.

892 103. Munro GD (2010) The scientific impotence excuse: discounting belief-threatening scientific 893 abstracts. J Appl Soc Psychol 40: 579-600.

894 104. Detterman DK, Gabriel LT, Ruthsatz JM (1998) Absurd environmentalism. Behav Brain Sci 895 21: 411-412.

896 105. Tooby J, Cosmides L (1992) The psychological foundations of culture. In: Barkow JH,

897 Cosmides L, Tooby J, editors. The adapted mind: Evolutionary psychology and the

898 generation of culture. New York, NY: Oxford University Press. pp. 19-136.

899 106. Hanson SK (2004) The life of Helen Stephens: the Fulton flash. Carbondale, IL: Southern $900 \quad$ Illinois University Press.

901 107. Mallon W (1995) Wilma Rudolph. In: Porter DL, editor. African-American sports greats: a 902 biographical dictionary. Westport, CT: Greenwood Press. pp. 288-291.

903 108. Rudolph W (1977) Wilma. New York, NY: New American Library.

904 109. Schraff A (2004) Wilma Rudolph. The greatest woman sprinter in history. Berkeley Hts., 905 NJ: Enslow Publishers, Inc. 
906 110. Carlson LH (1995) Wyomia Tyus-Tillman. In: Porter DL, editor. African-American sports

907 greats: a biographical dictionary. Westport, CT: Greenwood Press. pp. 349-351.

908 111. Tyus W (2010) Wyomia Tyus. In: Walter JC, Tida M, editors. Better than the best: black

909 athletes speak, 1920-2007. Seattle, WA: University of Washington Press. pp. 133-149.

910 112. Hornbuckle AR (1995) Evelyn Ashford Washington. In: Porter DL, editor. African-

911 American sports greats: a biographical dictionary. Westport, CT: Greenwood Press. pp. 361-

912363.

913 113. Hornbuckle AR (1995) Florence Griffith Joyner. In: Porter DL, editor. African-American

914 sports greats: a biographical dictionary. Westport, CT: Greenwood Press. pp. 125-127.

915 114. Christie JR (1988) Ben Johnson: the fastest man on Earth. Toronto, Canada: McClelland-

916 Bantam, Inc.

917 115. Hornbuckle AR (1995) Gail Devers. In: Porter DL, editor. African-American sports greats:

918 a biographical dictionary. Westport, CT: Greenwood Press. pp. 69-72.

919 116. Johnson M (1996) Slaying the dragon. New York, NY: Regan Books.

920 117. Gutman W (2000) Marion Jones: the fastest woman in the world. New York, NY: Pocket

$921 \quad$ Books.

922 118. Maloney M (2007) Catch him if you can. Available:

923 http://www.kentucky.com/mld/kentucky/news/local/16830215.htm via the Internet.

924 119. Hendershott J (2007) T\&FN interview: Tyson Gay. Track \& Field News September: 14-16.

925 120. Layden T (1997) Speed demons. Sports Illustrated 87: 50-52.

926 121. Hendershott J (2000) T\&FN interview: Maurice Greene. Track \& Field News February: 8-

9279.

928 122. Deford F (2001) Time bandits. Sports Illustrated 95: 53-63.

929 123. Nooden M (1991) Super power. Sports Illustrated 75: 44-49.

930 124. Hendershott J (2005) T\&FN interview: Justin Gatlin. Track \& Field News April: 8-10. 
931 125. Layden T (2004) Fast company. Sports Illustrated 101:

932 http://sportsillustrated.cnn.com/vault/article/magazine/MAG1112495/index/index.htm:

933 126. Gleason D (1980) Carl Lewis: T \& F N interview. Track \& Field News December: 50-51.

934 127. Hendershott J (1989) Athlete of the decade: Carl Lewis. Track \& Field News December:

$935 \quad 10-12$.

936 128. Denman E (2006) Available: http://www.nationalscholastic.org/nbon/article/221 via the

$937 \quad$ Internet.

938 129. Binder D (2012) Ryan Bailey story, circa 2007. Available:

939 http://trackfocus.com/sprints/ryan-bailey-story-circa-2007 via the Internet.

940 130. Anonymous Travis Padgett. Available: http://www.theacc.com/sports/c-track/spec-

941 rel/032307aac.html via the Internet.

942 131. Patton D Available: http://www.docpatton.com via the Internet.

943 132. Hendershott J (1994) T\&FN interview: Dennis Mitchell. Track \& Field News November:

$944 \quad 46-48$.

945 133. USATF (2000) Dennis Mitchell. Available:

946 http://www.usatf.org/athletes/bios/TrackAndFieldArchive/2000/mitchell.html via the

$947 \quad$ Internet.

948 134. USATF (no date) Leonard Scott. Available:

949 http://www.usatf.org/athletes/bios/Scott_Leonard.asp via the Internet.

950 135. Anonymous (no date) Andre Cason. Available: http://en.wikipedia.org/wiki/Andre_Cason $951 \quad$ via the Internet.

952 136. Hendershott J (1994) T\&FN interview: Andre Cason. Track \& Field News July: 48-49.

953 137. IAAF (no date) Andre Cason. Available: http://www.iaaf.org/athletes/united-states/andre954 cason via the Internet.

955 138. Weiss D (1991) Homecoming for TCU star. Available: http://articles.philly.com/1991-04- 
19/sports/25778039_1_penn-relays-jon-drummond-tcu via the Internet.

957 139. Reid R (1999) Jon Drummond is a fixture at the Penn Relays the former Overbrook sprinter

958 and Olympic medalist belongs. Available: http://articles.philly.com/1999-04-

959 22/sports/25521375_1_jon-drummond-leadoff-leg-105th-penn-relays via the Internet.

960 140. Hendershott J (2002) T\&FN interview-the world's fastest human: Tim Montgomery. Track

961 \& Field News November: 28-30.

962 141. Abrahamson A (2003) Holding fast: Montgomery has Maion, his faith and a world record in 963 the 100, so why would he possibly need a coach? Available:

$964 \mathrm{http}: / /$ articles.latimes.com/2003/jun/19/sports/sp-track19 via the Internet.

965 142. Fish M (2009) The fastest man in the prison yard. Available:

966 http://sports.espn.go.com/oly/trackandfield/columns/story?

967 columnist=fish_mikeandid=4487014. via the Internet.

968 143. USATF (no date) Tim Harden. Available:

969 http://www.usatf.org/athletes/bios/TrackAndFieldArchive/2001/Harden_Tim.asp via the

$970 \quad$ Internet.

971 144. Martin S (1980) Tide's Calvin Smith blazing a trail in track. The Tuscaloosa News B: 1, 11.

972 145. Lee Y (1987) T\&FN interview: Calvin Smith. Track \& Field News 44-46.

973 146. Hendershott J (1993) T\&FN interview: Michael Marsh. Track \& Field News July: 36-37.

974 147. USATF (1997) Michael Marsh. Available:

975 http://www.usatf.org/athletes/bios/TrackAndFieldArchive/1997/marsh.asp via the Internet.

976 148. Ainsworth J (2012) Central grad Ivory Williams hopes his high school coach can help him

977 reach Olympic dream. Available: http://www.beaumontenterprise.com/sports

978 /hs/article/Central-grad-Ivory-Williams-hopes-his-high-school-3685911.php via the

979 Internet.

980 149. Korth J (2000) Sprinter's speed no gimmick. Available: 
982 Internet.

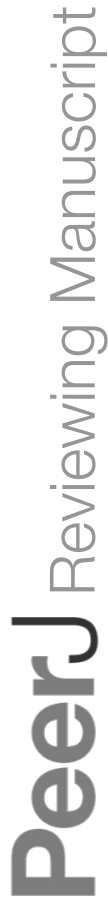




\section{Table 1 (on next page)}

Male and female $100 \mathrm{~m}$ and $200 \mathrm{~m}$ Olympic gold medal winners for which autobiographies or biographies published in print were available. 
1 Table 1. Male and female $100 \mathrm{~m}$ and $200 \mathrm{~m}$ Olympic gold medal winners for which 2 autobiographies or biographies published in print were available.

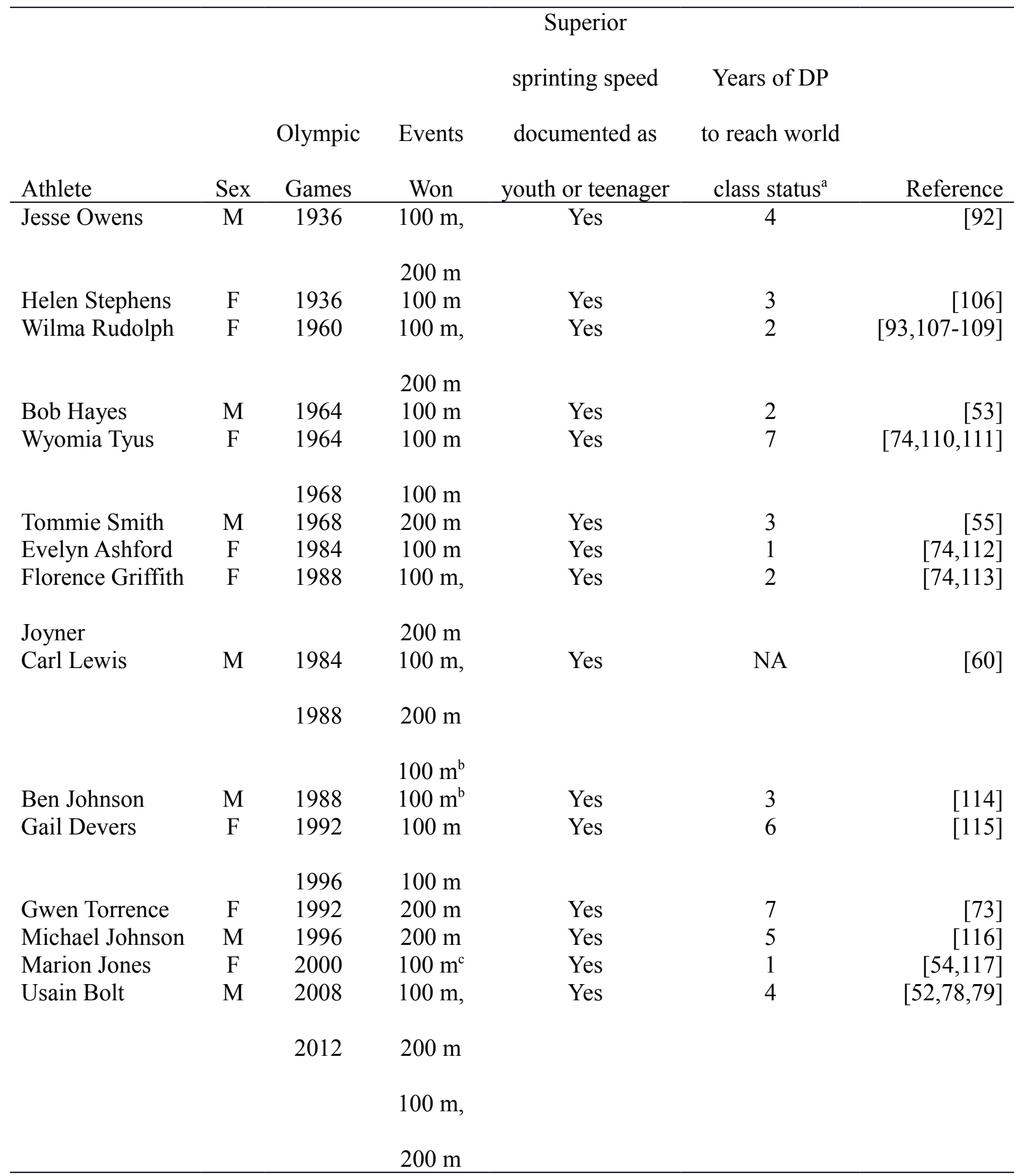


$3 \quad{ }^{a}$ Defined as representing their country in international competitions (e.g., Olympic Games, World 4 Championships).

$5 \quad{ }^{b}$ Awarded the gold medal because Ben Johnson was disqualified as winner for using performance 6 enhancing drugs.

$7 \quad$ Disqualified as winner for using performance enhancing drugs. 


\section{Table 2 (on next page)}

Histories of the 20 fastest male American $100 \mathrm{~m}$ sprinters. Ranking of sprinters and fastest $100 \mathrm{~m}$ times at age 19 and older obtained from U. S. A. Track and Field (www.usatf.org) and I. A. A. F. (www. 
1 Table 2. Histories of the 20 fastest male American $100 \mathrm{~m}$ sprinters. Ranking of sprinters and fastest $100 \mathrm{~m}$ times at age 19 and older

2 obtained from U. S. A. Track and Field (www.usatf.org) and I. A. A. F. (www.iaaf.org) performance data.

\begin{tabular}{|c|c|c|c|c|c|c|c|c|c|}
\hline Ran & Name & $\begin{array}{l}\text { Date } \\
\text { of } \\
\text { Birt } \\
\\
h\end{array}$ & $\begin{array}{l}\text { Age when superior } \\
\text { sprinting speed } \\
\text { first recognized }\end{array}$ & $\begin{array}{l}\text { Age at } \\
\text { start of } \\
\mathrm{DP}^{\mathrm{c}}\end{array}$ & $\begin{array}{l}\text { Fastest } \\
\text { time at } \\
\text { age } 19\end{array}$ & $\begin{array}{l}\text { Fastest } \\
\text { time } \\
\end{array}$ & $\begin{array}{c}\text { Percent } \\
\text { improvement }^{\mathrm{a}}\end{array}$ & $\begin{array}{c}\text { Years from } \\
\text { start of DP to } \\
\text { world class } \\
\text { status }^{\mathrm{b}}\end{array}$ & Reference \\
\hline 1 & T. Gay & 1982 & 13 & 13 & 10.27 & 9.69 & 5.64 & 9 & {$[118,119]$} \\
\hline 2 & M. Greene & 1974 & 8 & 8 & 10.19 & 9.79 & 3.93 & 13 & [120-122] \\
\hline 3 & L. Burrell $\simeq$ & -1967 & 14 & 14 & 10.46 & 9.85 & 5.83 & 7 & {$[58,123]$} \\
\hline 4 & J. Gatlin & 1982 & 14 & 14 & 10.08 & 9.85 & 2.28 & 6 & {$[124,125]$} \\
\hline 5 & C. Lewis & 1961 & $\mathrm{NA}^{\mathrm{e}}$ & NA & 10.00 & 9.86 & 1.40 & NA & {$[60,84,126,127]$} \\
\hline 6 & S. Crawford & 1978 & 12 & 12 & 10.51 & 9.88 & 5.99 & 11 & [128] \\
\hline 7 & W. Dix & 1986 & 9 & 14 & 10.06 & 9.88 & 1.79 & 4 & [61] \\
\hline 8 & R. Bailey & 1989 & 15 & 15 & 10.28 & 9.88 & 3.89 & 5 & [129] \\
\hline 9 & T. Padgett & 1986 & NA & NA & 10.00 & 9.89 & 1.10 & NA & [130] \\
\hline 10 & D. Patton & 1977 & NA & NA & NA & 9.89 & NA & NA & [131] \\
\hline 11 & D. Mitchell & 1966 & 6 & 6 & 10.21 & 9.91 & 2.94 & 15 & {$[132,133]$} \\
\hline 12 & L. Scott & 1980 & NA & NA & 10.29 & 9.91 & 3.69 & NA & [134] \\
\hline 13 & $\begin{array}{l}\text { A. Cason } \\
\text { J. }\end{array}$ & $\begin{array}{l}1969 \\
1968\end{array}$ & NA & NA & 10.08 & 9.92 & 1.59 & NA & $\begin{array}{c}{[135-137]} \\
{[138,139]}\end{array}$ \\
\hline 14 & $\begin{array}{l}\text { Drummond } \\
\mathrm{T} \text {. }\end{array}$ & & 9 & 9 & 10.25 & 9.92 & 3.22 & 14 & \\
\hline 15 & Montgomery & 1975 & NA & NA & 10.11 & 9.92 & 1.88 & NA & [140-142] \\
\hline 16 & T. Harden & 1974 & NA & NA & 10.32 & 9.92 & 3.88 & NA & [143] \\
\hline 17 & C. Smith & 1961 & NA- & NA & 10.17 & 9.93 & 2.36 & NA & {$[144,145]$} \\
\hline 18 & M. Marsh & 1967 & 11 & 11 & 10.22 & 9.93 & 2.84 & 8 & {$[146,147]$} \\
\hline
\end{tabular}


$\begin{array}{ll}\text { I. Williams } & 1985 \\ \text { B. Williams } & 1978\end{array}$

$\begin{array}{ll}985 & 16 \\ 1978 & 16\end{array}$

16

16

10.29

10.45

9.93

3.50

4.88

Percent improvement $=1$ - (fastest $100 \mathrm{~m}-100 \mathrm{~m}$ time at age 19$) \times 100$.

$4{ }^{\text {b} W o r l d ~ c l a s s ~ s t a t u s ~ d e f i n e d ~ a s ~ e i t h e r ~(1) ~ r e p r e s e n t i n g ~ t h e ~ U . ~ S . ~ A . ~ a t ~ i n t e r n a t i o n a l ~ c h a m p i o n s h i p s ~(e . g ., ~ P a n ~ A m e r i c a n ~ G a m e s, ~ W o r l d ~}$

5 Championships, Olympic Games) in an individual sprint event or as a member of a relay team or (2) participating in the U.S. Olympic

6 Trials which requires the athlete to meet Olympic A or B standards to qualify to compete at the Trials.

$7 \quad{ }^{\mathrm{c}} \mathrm{DP}=$ deliberate practice.

$8{ }^{\mathrm{d}} \mathrm{C}$. Lewis was the $5^{\mathrm{th}}$ 齐anked long jumper in the world and $2^{\text {nd }}$ ranked long jumper in the U. S. A. by the age of 18.

$9 \quad{ }^{\mathrm{e}} \mathrm{NA}=$ no data/information available.

10

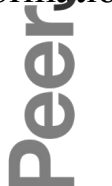




\section{Table 3 (on next page)}

Recollections of childhood and adolescent athletic abilities of sprinters and throwers who qualified for the 2012 U. S. collegiate track and field outdoor championships. 
1 Table 3. Recollections of childhood and adolescent athletic abilities of sprinters and throwers

2 who qualified for the 2012 U. S. collegiate track and field outdoor championships.

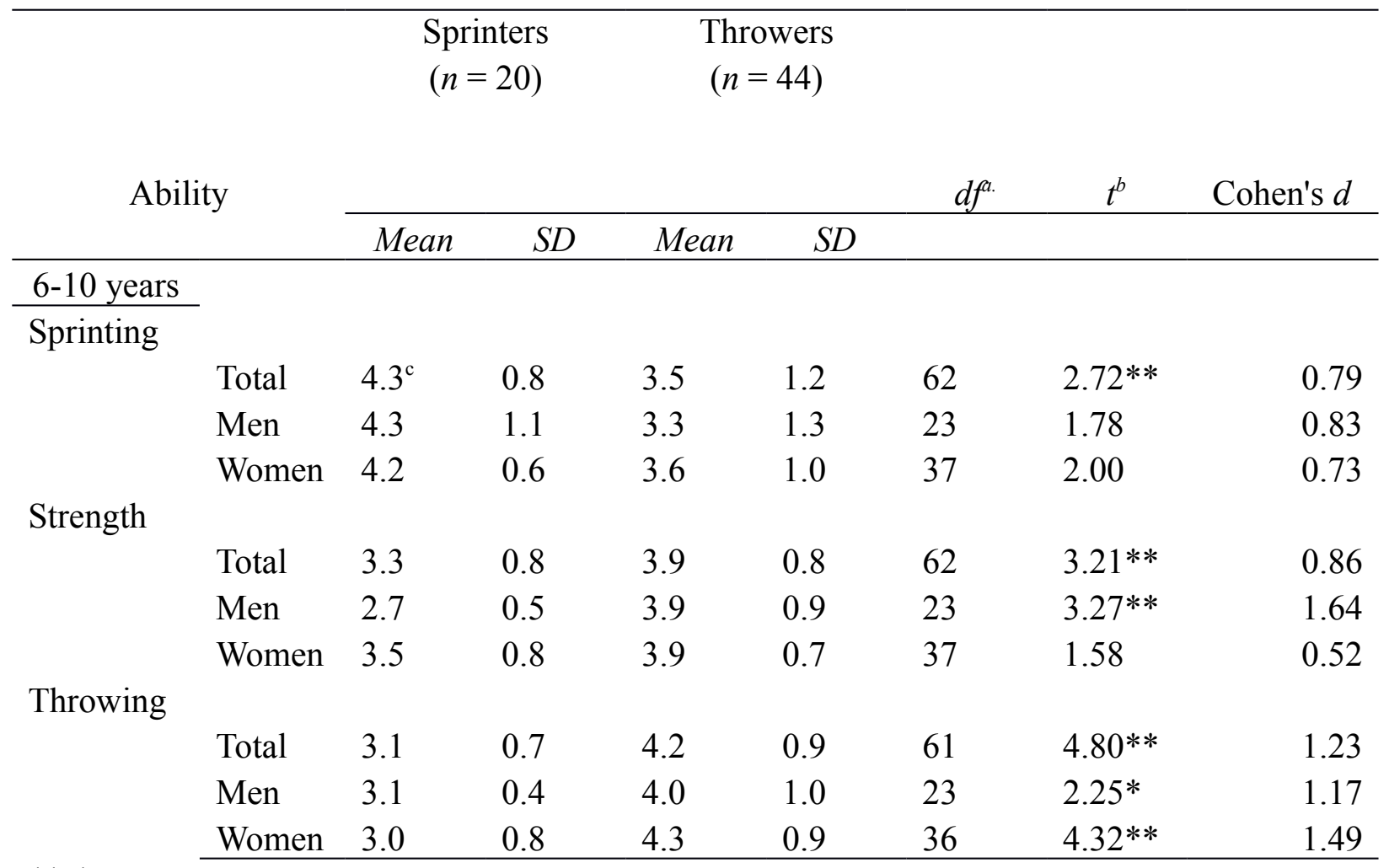

$11-15$

years

Sprinting

$\begin{array}{llllllll}\text { Total } & 4.2 & 0.7 & 3.2 & 1.0 & 62 & 3.88^{* *} & 1.10 \\ \text { Men } & 4.0 & 0.8 & 3.1 & 1.0 & 23 & 2.22^{*} & 1.04 \\ \text { Women } & 4.2 & 0.7 & 3.3 & 1.0 & 37 & 3.07^{* *} & 1.10\end{array}$

Strength

$\begin{array}{llllllll}\text { Total } & 3.5 & 0.9 & 4.3 & 0.8 & 61 & 3.22^{* *} & 0.87 \\ \text { Men } & 2.7 & 0.5 & 4.1 & 1.0 & 23 & 3.37^{* *} & 1.73 \\ \text { Women } & 4.0 & 0.7 & 4.4 & 0.6 & 36 & 1.76 & 0.58\end{array}$

Throwing

\begin{tabular}{llllllll} 
Total & 3.1 & 0.7 & 4.6 & 0.6 & 62 & $8.63^{* *}$ & 2.25 \\
Men & 3.0 & 0.6 & 4.5 & 0.7 & 23 & $4.98^{* *}$ & 2.31 \\
Women & 3.2 & 0.8 & 4.7 & 0.5 & 37 & $7.06^{* *}$ & 2.24 \\
\hline
\end{tabular}

3 a Degrees of freedom differ because some participants did not complete all items.

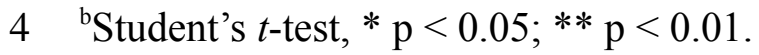


$5 \quad{ }^{\circ}$ Values in table represent scores on surveys on a five point scale with higher scores indicating 6 higher self-rated ability; see Study 3 Methods for scales. 


\section{Table 4 (on next page)}

U. S. collegiate sprinters' recollections of their onset of training and best performances. 
1 Table 4. U. S. collegiate sprinters' recollections of their onset of training and best performances.

\begin{tabular}{|c|c|c|c|c|c|c|c|c|c|c|}
\hline & & & & Age & & & & & & \\
\hline & & & & First & & & & & & \\
\hline & & & & Year & First & & Lifetime & Best Pert & formance & \\
\hline & NCA & & Began & High & Year & & & & & \\
\hline Sex & A & Age & Traini & Schoo & High & & & & & \\
\hline & Divisi & & ng & 1 & Schoo & & & & & \\
\hline & on & & & & 1 Best & & & & & \\
\hline & & & & & Perfor & & & & & \\
\hline & & & & & manc & & & & & \\
\hline & & & & & $\mathrm{e}$ & & & & & \\
\hline & & & & & $100 \mathrm{~m}$ & $200 \mathrm{~m}$ & $400 \mathrm{~m}$ & $100 \mathrm{~m}$ & $200 \mathrm{~m}$ & $400 \mathrm{~m}$ \\
\hline $\mathrm{F}$ & I & 18 & $* 17^{\mathrm{a}}$ & 14 & 12.7 & 26.3 & $\mathrm{NA}^{\mathrm{b}}$ & NA & NA & 51.1 \\
\hline F & I & 22 & 18 & 14 & NA & NA & $59 . X^{c}$ & 11.4 & 23.4 & 56.X \\
\hline $\mathrm{F}$ & I & 24 & $* 21$ & $* 17$ & NA & NA & NA & 11.1 & 23.1 & NA \\
\hline F & II & 23 & 15 & 14 & NA & 26.X & 58.X & NA & 24.1 & 53.0 \\
\hline $\mathrm{F}$ & III & 21 & $* 13$ & 14 & 13.X & $28 . \mathrm{X}$ & NA & 11.9 & 26.0 & 62.2 \\
\hline $\mathrm{F}$ & III & 22 & $* 15$ & 15 & 12.7 & 27.2 & NA & 12.0 & 25.4 & NA \\
\hline $\mathrm{F}$ & III & 23 & *19 & $* 15$ & 13.1 & 26.X & 60.0 & NA & 25.3 & 56.4 \\
\hline F & III & 20 & $* 16$ & $* 15$ & 13.5 & 26.8 & 59.9 & 12.4 & 24.5 & 55.5 \\
\hline F & III & 22 & $* 17$ & $* 17$ & 13.X & 27.X & 59.X & 12.0 & 24.3 & 55.2 \\
\hline F & III & 21 & $* 16$ & $* 15$ & 13.X & 27.X & 61.X & 13.X & 26.0 & 56.8 \\
\hline F & III & 20 & $* 13$ & $* 14$ & 15.X & 27.X & 62.X & 12.4 & 24.6 & 58.1 \\
\hline F & III & 19 & $* 15$ & 14 & NA & 28.X & 63.X & NA & 24.9 & 54.8 \\
\hline $\mathrm{F}$ & III & 21 & 18 & NA & NA & NA & NA & 12.9 & 26.0 & 56.5 \\
\hline $\mathrm{M}$ & I & 20 & $* 15$ & 14 & 11.0 & 22.5 & 52.9 & 10.2 & 21.1 & 49.2 \\
\hline M & I & 20 & 18 & $* 16$ & 11.3 & 23.5 & 53.4 & 10.6 & 20.9 & 46.0 \\
\hline M & I & 20 & $* 16$ & $* 15$ & 11.2 & 23.5 & 54.X & 10.9 & 21.2 & 46.3 \\
\hline M & II & 22 & NA & NA & NA & NA & NA & NA & 21.5 & 47.1 \\
\hline $\mathrm{M}$ & II & 21 & $* 17$ & 15 & 11.3 & 22.8 & 49.9 & 10.6 & 21.1 & 46.1 \\
\hline M & III & 22 & 14 & 14 & NA & NA & 57.X & 10.6 & 21.3 & 48.8 \\
\hline
\end{tabular}




\begin{tabular}{lllllllllll}
$\mathrm{M}$ & III & 21 & 17 & $* 16$ & NA & 22.2 & 49.4 & NA & 22.1 & 47.4 \\
\hline
\end{tabular}

2 a* Indicates age estimated from reported grade (e.g., 9 th grade $=15$ years).

$3 \quad{ }^{b} \mathrm{NA}=$ no data provided by athlete.

$4 \quad$ 'Performances including an "X" after the decimal indicate uncertainty about exact time. 


\section{Figure 1}

The number of years of training required to reach world class status by male and female Olympic 100 and $200 \mathrm{~m}$ champions and the 20 fastest $100 \mathrm{~m}$ American male sprinters.

Figure 1. The number of years of training required to reach world class status by male and female Olympic 100 and 200 m champions and the 20 fastest 100 m American male sprinters.

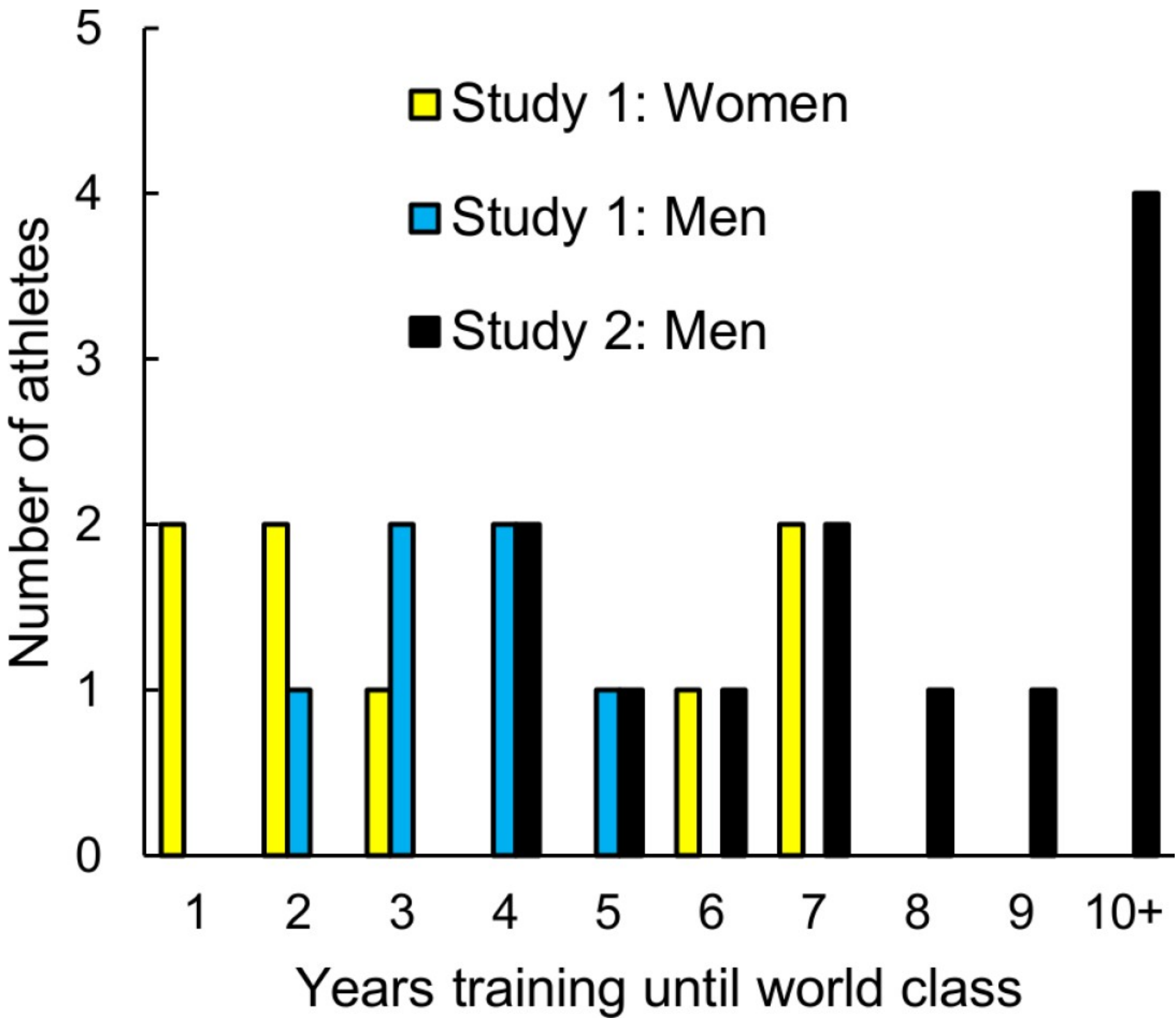




\section{Figure 2}

The recollections by Division I, II, and III qualifiers for the 2012 National Collegiate Athletic Association (NCAA) Outdoor Track and Field Championships of their sprinting, strength, and over-hand $t$

Figure. 2. The recollections by Division I, II, and III qualifiers for the 2012 National Collegiate Athletic Association (NCAA) Outdoor Track and Field Championships of their sprinting, strength, and over-hand throwing abilities as youths relative to their peers. Relative ability: 5 $=$ much faster, stronger, or better; $4=$ faster, stronger, or better; $3=$ about the same; $2=$ slower, weaker, or worse. Mean relative ability plus one standard error of the mean is illustrated for each category.

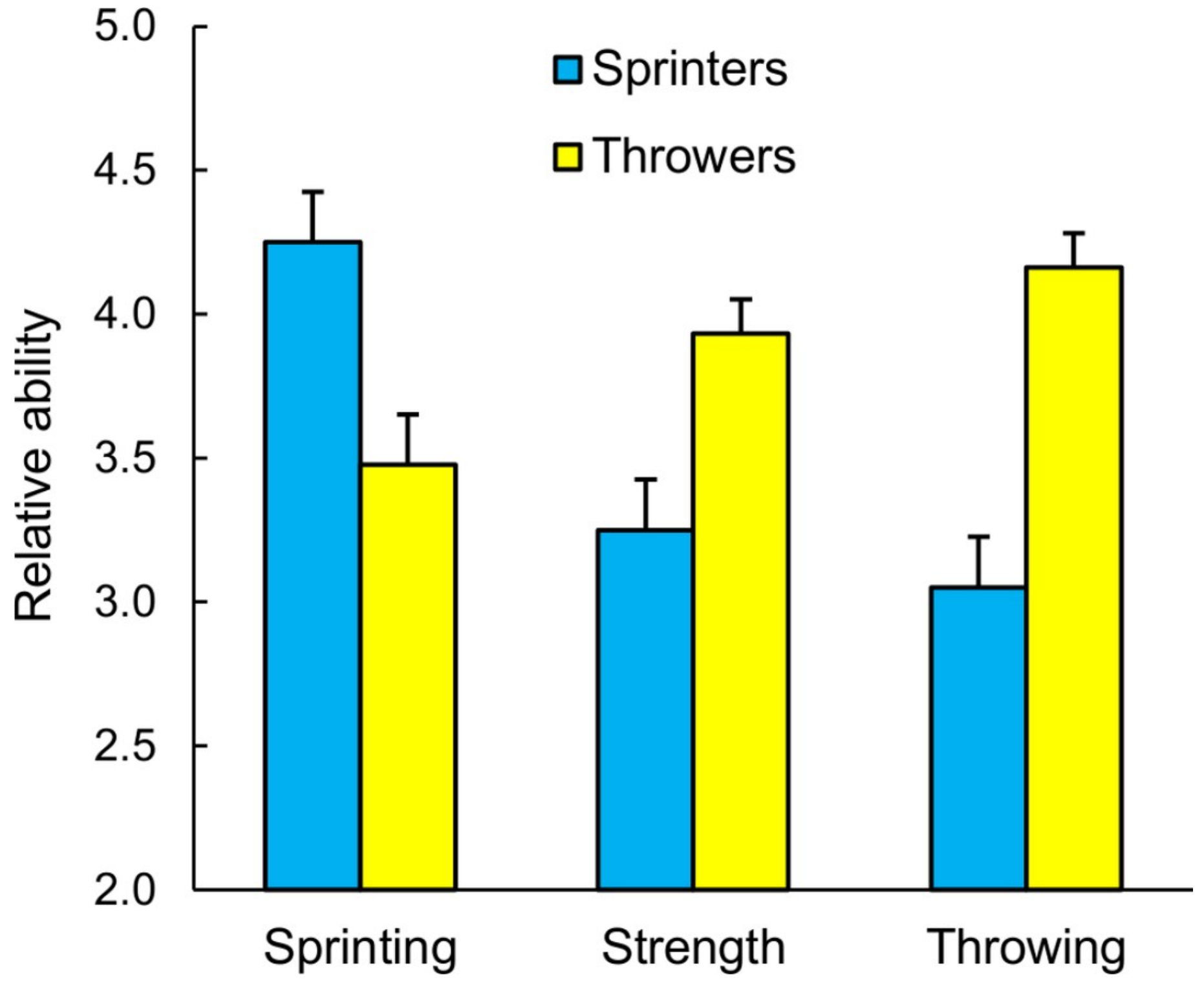

